\title{
Projects AND Conference REPORTS
}

The Third Woodbrooke-Mingana Symposium on Arab Christianity and Islam

Woodbrooke, Birmingham, UK, 7-9 September 1998

\section{SIDNEY H. GRIFFITH, INSTITUTE OF CHRISTIAN ORIENTAL RESEARCH}

[1] The Third Woodbrooke-Mingana Symposium on Arab Christianity and Islam met at Woodbrooke, The Selly Oak Colleges, Birmingham, UK, from 7-9 September 1998. The convener of the symposium was Dr David Thomas of Selly Oak's Centre for the Study of Islam and Christian-Muslim Relations. The theme was "Arab Christianity in Bilad al-Sham in the pre-Ottoman Period." A highlight of the event was a tour conducted by Mrs Meline Nielsen of the Mingana Room, in Selly Oak's new Orchard Learning Resources Centre, where the important collection of Syriac and Arab Christian manuscripts are now stored.

In the course of the scholarly sessions, the following papers were presented and discussed: Barbara Roggema, "A Christian Reading of the Qur'an: ththe Arabic Version of the Legend of Sergius-Bahira and its Use of Qur'an and Sira;" Samir K. Samir, "Muhammad as Seen by Timothy I (781-824) and some other Arab Christians;" Seta B. Dadoyan, "The Armenian Intermezzo in Bilad al-Sham: 10th to 12th Centuries;" Mor Gregorios Yohanna Ibrahim, "The Caliph al-Ma'mun and the Christians according to Michael the Syrian;" Sidney H. Griffith, “"Melkites,' 'Jacobites' and the Christological Controversy in Arabic in Ninth Century Arabia: the Disputes of Theodore Abu Qurra and Habib ibn Khidma Abu Ra'ita;" Mark Swanson, "The Martyrdome of Abd al-Masih of Mount Sinai (Qays al-Ghassani)." Presentations were also made by Dr Lawrence I. Conrad of the Wellcome Institute, London, Professor Lucy-Anne Hunt of Manchester Metropolitan University, and Mr. Peter Starr of Cambridge University. 
IVth World Syriac Conference

St. Ephrem Ecumenical Research Institute (SEERI)

Kottayam, Kerala, India, 6-12 September 1998.

\section{DAVID G.K. TAYLOR, UNIVERSITY OF BIRMINGHAM}

[1] Since the First World Syriac Conference in 1987 the Syriac conferences hosted by SEERI have rapidly established themselves as important and influential gatherings for syriacisants from around the world, and have gained a well deserved reputation not only for the quality both of the papers given and of the ensuing discussion, but also for the warm and generous welcome given to the participants. In all of these respects the Fourth World Syriac Conference managed to surpass the very high standards set in previous years.

The growing importance of SEERI's academic role both locally and internationally was clearly demonstrated in the opening session on the 6th of September when the conference participants were addressed by senior representatives of the main churches of Syriac origin in Kerala, by several international scholars, and by Professor V.N. Rajasekharan Pillai, the Vice Chancellor of Mahatma Gandhi University. As many readers of Hugoye will know, the Mahatma Gandhi University now validates both the Ph.D. and MA degree programmes in Syriac provided by SEERI. Another sign of development and progress was the inauguration of SEERI's new web site (http://www.keralaonline.com/seeri/) during the opening session.

The serious work of the conference began on the Monday morning, with a truly stakhanovite timetable. On most days there were as many as seven papers before lunch, and six afterwards. By the end of the week seventy formal papers had been presented, of which approximately half were given by Indian scholars and half by scholars from abroad. (Many other scholars were present who did not formally present papers, but chaired sessions or were active in debate.) With twenty minutes allocated for the papers and ten minutes for discussion it will come as no surprise to hear that many of us overshot these limits. One positive consequence of this was that many passionate debates about matters Syriac took place over meals and glasses of tea. Indeed, this was often where one was asked the truly searching and revealing questions. 
It would be impossible here to give a summary of each of the papers, and invidious to make a selection from them, so I will simply provide a survey of the topics covered. (Details of the participants and of the titles of their papers can be found on the SEERI web page mentioned above, although this has not yet been updated to reflect changes in the programme. The papers themselves are to be published in the next edition of The Harp.)

Few areas of Syriac-related study were neglected, although papers dealing with liturgy and theology tended to dominate. Amongst the former were papers on the office and function of Readers; the liturgical commentary of George of Arbel; the East Syrian Malabar Breviary of 1862; Baptism in the Church of the East; "Mercy" in West Syrian liturgy; the feast of the Assumption in the Syriac tradition; the East Syrian liturgy of the Hours; the Great Lent; the development of the Melkite rite; iconographic inscriptions; the musical traditions of the East and West Syrian churches of Kerala; and many others.

The theological sessions included papers on Theodosius of Alexandria; John of Mosul; Philoxenus of Mabbug; the Christology of Timothy I; the biography of Bar Hebraeus and his understanding of incarnation; Salvation in Jacob of Serugh; the polemics of Dionysios Bar Salibi; the Syriac versions of PseudoDenys the Areopagite and of Gregory Nazianzen; Trinitarian terminology in the Diatessaron commentary; and, of course, several papers on Ephrem, examining his poetry, his exegesis of the parables, his biblical hermeneutics, his idea of revelation as divine pedagogy, his interpretation of Christ as the second Adam, and his understanding of salvation history as a healing process.

Amongst the historical papers were accounts of the Assyrian church in the twentieth century, and of the Assyro-Chaldean communities in Persia from the nineteenth century to the first world war; papers dealing with the engagement with Nestorian theology in the thirteenth century German court and later by Luther; the life and cult of Mar Qardagh; Shubhalmaran's practical advice for monks; Mission in Central Asia; and the chronicle of Elias Bar Shinaya.

There was also a good crop of papers dealing with the Syriac versions of the Scriptures. These included an examination of the Old Testament citations in the memre of Jacob of Serugh, and studies of the Peshitta Old Testament and its rivals; the Psalm 
Commentary of Daniel of Salah; Jacob of Edessa's exegesis of Genesis; symbols of authority in the Old Testament; and the New Testament canon.

Several papers addressed ecumenical issues, and others engaged with linguistic matters such as the influence of Syriac on the vocabulary of the languages of South India, the revival of Classical Syriac as a living language, the future of Syriac lexicography, and the technical terminology of the Syriac Pharmacopoeia.

Particular mention should, however, be made of a longer illustrated presentation given by Françoise Briquel Chatonnet and Jacob Thekeparampil concerning Syriac manuscripts and inscriptions in Kerala. This presentation drew upon several years of active research, which is to be fully published elsewhere, and emphasised, amongst other serious matters, the importance of Syriac inscriptions and manuscript colophons for our knowledge of the history of the Syrian churches in Kerala. It also provided the first serious discussion of the development of Syriac palaeography in Kerala, a subject that hitherto has been much neglected. (Incidentally, it might also be noticed that this research provides an excellent example of the fruits to be gained from academic collaboration between Indian scholars and their counterparts from abroad.)

I have no doubt that in this crude summary of papers I will have forgotten to refer to several important contributions, and for this I ask pardon, but I hope that it provides at least some impression of the extraordinary range of topics discussed and of the breadth of expertise present at the conference.

[12] Harder to communicate is the overwhelmingly cheerful and friendly atmosphere of the conference. This was partly generated by the simple process of enthusiasts for Syriac culture coming together from all over the world and sharing their passionate enthusiasm with one another, but above all else it was due to the outstanding generosity and efficient organisation of Jacob Thekeparampil and his many colleagues. We wanted for nothing. By day we were fed wonderfully by the sisters, and by night we were entertained sumptuously by churches and Christian communities in the Kottayam region. After the conference the hospitality continued, with clergy and churches further afield, in Pampakuda, Trichur, Thozhiyur, Cochin, and elsewhere, inviting us 
into their homes and entertaining us regally. An abiding memory for all the participants in these evenings will be the sound of singing, for at times it seemed that at the drop of a hat both hosts and guests would burst into song! During these occasions we all learnt a great deal about the history and current concerns of our hosts, and many new friends were made. It is to be hoped that this too will lead to future co-operation and collaboration.

[13] One practical way of fostering this collaboration (if I may take this opportunity to advertise!) is membership of the Association of the Friends of SEERI: $\$ 29$ supports their important work and gains substantial discounts off their publications, whereas $\$ 115$ a year entitles the member to free copies of their publications and hospitality in India. For further details contact F. Briquel Chatonnet, 14, Boulevard Jourdan, 75014 Paris, France.

[14] In summary, this was a highly stimulating conference that encouraged participants to work hard and then allowed them to play hard! All scholars interested in Syriac studies are strongly encouraged to take part in the next conference in four years time. 
Second Symposium Syro-Arabicum

\section{Herman Teule, University OF NijMEgen}

[1] The second Symposium Syro-Arabicum (17-19 September 1998), successor of the first symposium held in Kaslik in September 1995, was organised by the CEDRAC, the formerly independent research institute in Christian Arabic Studies (Director: Fr. Samir Khalil Samir), which, now, has established more institutional links with the Universite St. Joseph in Beirut. Father Selim Abou, rector of the USJ, opened the symposium, stressing the importance of Christian Arabic Studies especially from the point of view of their relevance for the present situation of the Christians in the Middle East. All sessions took place in the nice and quiet monastery of Sayyidat al-Bi'r, not far from the Lebanese capital.

As a matter of fact, only a limited part of this congress was devoted to Syriac Studies, starting the first day with three contributions in the field of exegesis: A. Juckel, on the Harklean Version of the New Testament; M. Accad, about the Islamic context of the later Syriac Fathers when reinterpreting the New Testament, and A. Chahwan (already in the field of Christian Arabic Studies), with a study about the concept of Judaism in the Psalm Commentary of $b$. al-Tayyib. Funeral practices of the Maronites were discussed by R. Jabre Mouawad; H. Teule dealt with the ascetical work of John Nâqar (Edessa, 8th cent.), whereas P. Sfeir presented some of the Syriac mss. in the collection of the Library of Bkerké. L. Van Rompay discussed the Syriac inscriptions of the recently discovered wall-paintings in Dayr as-Suryân. And finally, the influence of Al-Ghazâlî on Bar Hebraeus' Ethicon was the subject matter of Hanna Khadra's contribution.

The remaining conferences were devoted to Art (Wall paintings in Dayr as-Suryân by K. Innemee; Medieval frescos by N. Helou and the Melkite Iconographical School of Jerusalem by L. Hosri) and to many different aspects of Christian Arabic Literature. Of special interest for Syriac scholars are probably the contributions by S.M. Edris (Comparative Study between Johannes b. al-Macdani and Avicenna), S. Khalil Samir (the influence of al-Qiftî on the Mukhtasar Tarîkh ad-Duwal of Ibn al- Ibri) and S. Cabrol (The Anbârîs-s, a family of Nestorian kuttâb under the first Abbasids) 
Among the other CA authors discussed during this conference, one should mention especially the Maronite Patriarch Estephan Duwayhî (1630-1704), with contributions about his theology, and his historiographical and theological writings. The interest in the work of Duwayhi resulted in the creation of a research group around the work of the Maronite Patriarch; Ray Jabre Mouawad will act as the first coordinator.

One of the reasons for organizing a "Symposium SyroArabicum" in Lebanon, in addition to the already classical "Symposia Syriaca" followed, since 1980, by the "Conferences on Christian Arabic Studies" which took place in European countries, was the absence-for various reasons (financial, political...) —of Middle Eastern Scholars. This 2nd Symposium Syriacum was indeed an excellent occasion to meet Lebanese scholars working in various domains of $\mathrm{CA}$ and whose publications are not always easily accessible or known to western readers. Unfortunately, this time, the participation of western scholars was rather limited which made that this conference was almost the opposite of the Symposium Syriacum. Apparently, most western scholars preferred Birmingham or Kerala or were, who knows, somewhat tired of the increasing number of congresses.

[6] Our thanks are due to Father Samir Khalil Samir and his collaborators for the perfect organization of the congress and to Ray Moawad Jabre for the pleasant and interesting excursion to the Qaddisha Valley and the old Maronite Patriarchal See of Qannubin. The papers will be published in Parole de l'Orient. The next symposium will take place in in the year 2001. 
